Gut, 1961, 2, 119

\title{
The influence of cortisone on the parietal cell population of the stomach in the dog
}

\author{
N. C. R. W. REID, R. M. HACKETT, AND R. B. WELBOURN \\ From the Departments of Pathology and Surgery, The Queen's University of \\ Belfast, Northern Ireland
}

SYNOPSIS Two experiments were undertaken in dogs to discover the influence of cortisone on the parietal cell population of the stomach.

In one, samples of mucosa were removed at operation before and after the administration of cortisone in an average total dose of $39 \mathrm{mg}$. per $\mathrm{kg}$. (in seven days). The thickness of the mucosa was increased by $16 \%$ and the number of parietal cells per unit area was increased by $33 \%$.

In the other experiment different doses were given by daily intramuscular injection for various periods. The dogs were killed and their whole stomachs were examined. Cortisone in an average total dose of $28 \mathrm{mg}$. per $\mathrm{kg}$. (in three to seven days) increased the mean mucosal thickness by $27 \%$, increased the number of parietal cells underlying a unit area of the gastric mucosa by $50 \%$, and the total parietal cell population by a similar proportion. It did not influence the area of the gastric mucosa. Smaller doses of cortisone were less effective and larger ones tended to reduce the mucosal thickness and the number of parietal cells.

We have reported previously that pharmacological doses of cortisone increase by about $50 \%$ the maximal acid secretory response to histamine of denervated gastric pouches in dogs (Clarke, Neill, and Welbourn, 1960). Similar observations have been made with the augmented histamine test in patients receiving cortisone, prednisoline, and ACTH (Crean, 1960). A possible explanation of this finding was provided by our preliminary observation that cortisone and methyl prednisolone appeared to increase by about $50 \%$ the number of parietal cells in the gastric mucosa. The two experiments reported here were designed to provide more information about the effects of cortisone on the parietal cell population of the stomach.

\section{MATERIALS AND METHODS}

In the first experiment six mongrel dogs, weighing 8 to $10 \mathrm{~kg}$., were used. A biopsy of the whole thickness of the stomach wall, measuring about $2 \mathrm{~cm} . \times 1 \mathrm{~cm}$., was taken from each at open operaton. The biopsy was taken from the centre of the anterior wall in three and from the centre of the posterior wall in the other three. Each dog was then injected intramuscularly with cortisone acetate, $50 \mathrm{mg}$. daily for seven days, at the end of which time a second similar biopsy was taken from the opposite wall of the stomach. The dose of cortisone was a little higher than that of the moderate range in the second experiment (Table I).
The biopsies were flattened with the fingers until the mucosa was smooth, pinned out on cork, and fixed in dilute corrosive formol for one day. Vertical sections were then cut (at $7 \mu$ thickness), stained with haematooxylin and eosin and examined microscopically $(4 \mathrm{~mm}$. objective) with the help of an eyepiece micrometer. The total mucosal height (surface to muscularis mucosae) was measured at 10 representative sites and the number of parietal cell nuclei contained between two lines at right angles to the mucosal surface and $\mathbf{0 . 2 5} \mathrm{mm}$. apart was counted. The average mucosal height and the average number of parietal cells underlying a unit area $(7 \mu \times$ $1,000 \mu$ ) of mucosa were calculated for each specimen. The 'crude' parietal cell counts obtained by this method are higher than the true counts because they include parts of nuclei which extend into adjacent microtome sections. The 'corrected' counts were estimated by the method of Abercrombie (1946). ${ }^{1}$

In the second experiment 28 mongrel dogs, weighing between 8 and $15 \mathrm{~kg}$., were used. Nine served as controls and 19 received cortisone acetate by daily intramuscular injections of either $100 \mathrm{mg}$. or $50 \mathrm{mg}$. for different periods. The doses (in terms of $\mathrm{mg}$. per $\mathrm{kg}$. of body weight) and the times for which the cortisone was given are shown in Table I.

At the end of the experiment the dogs were killed by electrocution. The stomachs were removed immediately

\footnotetext{
${ }^{1}$ The calculated correction factor for nuclear overestimation (Abercrombie's formula 1) was $\mathbf{0 . 5 1}$. The mean observed diameter of the parietal cell nuclei ((largest + smallest) $\div 2$ ) was $6.68 \mu$. It was the same in vertical and horizontal sections and was not influenced by cortisone.
} 
TABLE I

DETAILS OF CORTISONE ADMINISTRATION

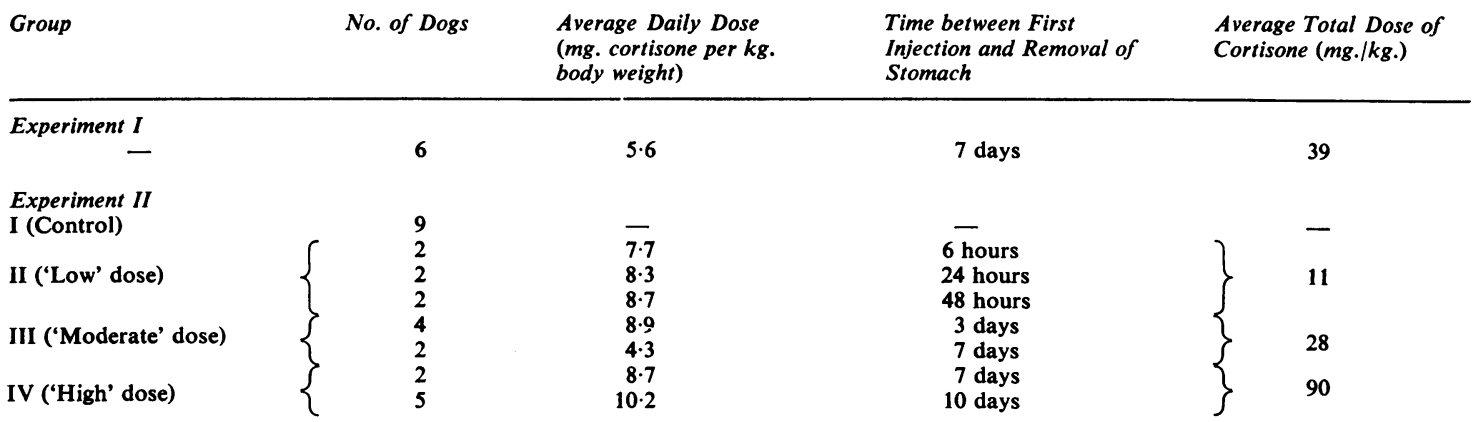

and treated in a manner similar to that described by Cox and Barnes (1945) and by Cox (1952). They were cut open along the greater curvature and adherent food was washed off with physiological saline. They were then stretched and pinned out on cork boards, so that as many as possible of the mucosal folds were flattened, and finally fixed in dilute corrosive formol for 24 hours.

After fixation the outline of the stomach was traced on paper. Three strips, about $1 \mathrm{~cm}$. wide, were cut from the entire length of each stomach, one from the lesser curvature (between the oesophagus and the pylorus) one from the middle of the anterior wall, and one from the middle of the posterior wall. The mucosa (together with the muscularis mucosae) of each strip was separated from the muscular coat and rolled up longitudinally, with its superficial surface inwards, embedded in paraffin wax, sectioned (at $7 \mu$ thickness), and stained with haematoxylin and eosin. In this way three longitudinal sections of each stomach, $7 \mu$ thick, were obtained.

The junction between the mucosa of the pyloric antrum and that of the body of the stomach was seen clearly under the microscope in each section and its distance from the pyloric end of the strip was measured. The positions of these junctions were marked on each tracing and straight lines were drawn from the point on the lesser curvature, through those on the dorsal and ventral walls, to the edges of the tracing. The area of the acid-secreting portion of each stomach (body plus fundus), thus delineated, was measured with a planimeter.
Ten representative sites from each section were examined microscopically (16 mm. objective) without knowledge of whether or not the dog had received cortisone. At each site the total mucosal height was measured and the number of parietal cell nuclei between two lines $0.34 \mathrm{~mm}$. apart was counted. From these figures the average total mucosal height and the average corrected parietal cell count per unit area $(7 \mu \times 1,000 \mu)$ of mucosal surface were calculated for each section as in the first experiment. Average values for each stomach were estimated from each set of three sections. Shrinkage of the sections after fixation (i.e., during the process of separation of the mucosa, rolling, embedding in wax, and staining) was found, by measurement, to be negligible and was ignored.

Three estimates were therefore available for each stomach: (1) The average mucosal height; (2) the average corrected number of parietal cells underlying an area of mucosal surface measuring $7 \mu \times 1,000 \mu$; and (3) the area of the acid-secreting mucosa. From these figures (2 and 3 ) the total number of parietal cells in the stomach was established.

\section{RESULTS}

EXPERIMENT I (Table II) Cortisone increased the height of the mucosa in each of the six stomachs, the mean increment being $16 \%$. The number of

TABLE II

INFLUENCE OF CORTISONE ON TOTAL HEIGHT OF GASTRIC MUCOSA AND ON NUMBER OF PARIETAL CELLS IN STOMACH (EXPERIMENT I)

\begin{tabular}{|c|c|c|c|c|c|c|}
\hline \multirow[t]{2}{*}{ Dog } & \multicolumn{3}{|c|}{ Total Height of Mucosa $(\mu)$} & \multicolumn{3}{|c|}{ No. of Parietal Cells per 7,000 sq. $\mu$. of Mucosal Surface } \\
\hline & Before & After & Difference (After-Before) & Before & After & Difference (After-Before) \\
\hline $\begin{array}{l}1 \\
2 \\
3 \\
4 \\
4 \\
5 \\
6\end{array}$ & $\begin{array}{l}600 \\
645 \\
590 \\
440 \\
530 \\
715\end{array}$ & $\begin{array}{l}620 \\
695 \\
680 \\
630 \\
670 \\
740\end{array}$ & $\begin{array}{l}+20(3 \%) \\
+50(8 \%) \\
+90(15 \%) \\
+190(43 \%) \\
+140(26 \%) \\
+25(3 \%)\end{array}$ & $\begin{array}{r}91 \cdot 0 \\
57 \cdot 5 \\
61 \cdot 2 \\
25 \cdot 7 \\
45 \cdot 3 \\
107 \cdot 0\end{array}$ & $\begin{array}{r}97 \cdot 5 \\
79 \cdot 1 \\
84 \cdot 0 \\
48 \cdot 3 \\
60 \cdot 2 \\
100 \cdot 0\end{array}$ & $\begin{array}{l}+6.5(7 \%) \\
+21.6(38 \%) \\
+22.8(57 \%) \\
+22.6(88 \%) \\
+14.9(33 \%) \\
-7.0(7 \%)\end{array}$ \\
\hline Mean & 587 & 673 & $+86^{1}(16 \%)$ & $64 \cdot 6$ & $78 \cdot 2$ & $+13.6^{2}(33 \%)$ \\
\hline
\end{tabular}

${ }^{1} t$ (paired data) $=3.10 \mathrm{D}$ of $\mathrm{F}=5 \quad 0.05>P>0.02$

st (paired data) $=2.78 \mathrm{D}$ of $\mathrm{F}=5 \quad 0.05>P>0.02$ 
TABLE III

INFLUENCE OF CORTISONE ON TOTAL HEIGHT OF GASTRIC MUCOSA AND ON NUMBER OF PARIETAL CELLS IN STOMACH (EXPERIMENT II)

\begin{tabular}{|c|c|c|c|c|c|c|}
\hline \multirow[t]{2}{*}{ Group } & \multirow[t]{2}{*}{$\begin{array}{l}\text { No. of } \\
\text { Dogs }\end{array}$} & \multirow{2}{*}{$\begin{array}{l}\text { Mean Total } \\
\text { Height of } \\
\text { Mucosa }(\mu)\end{array}$} & \multirow{2}{*}{$\begin{array}{l}\text { Mean No. of } \\
\text { Parietal Cells per } \\
7,000 \text { sq. } \mu \text { of } \\
\text { Mucosal Surface }\end{array}$} & \multirow{2}{*}{$\begin{array}{l}\text { Mean Area of } \\
\text { Acid-secreting } \\
\text { Mucosa }(s q . \mathrm{cm} .)\end{array}$} & \multicolumn{2}{|c|}{$\begin{array}{l}\text { Mean Total No. of Parietal Cells in } \\
\text { Stomach (millions) }\end{array}$} \\
\hline & & & & & Per Dog & $\begin{array}{l}\text { Per kg. of } \\
\text { Body Weight }\end{array}$ \\
\hline $\begin{array}{l}\text { I (Control) } \\
\text { II ('Low' dose) } \\
\text { III ('Moderate' dose) }\end{array}$ & $\begin{array}{l}9 \\
6 \\
6\end{array}$ & $\begin{array}{l}590 \pm 20(a, b) \\
707 \pm 49(a) \\
750 \pm 25(b)\end{array}$ & $\begin{array}{l}66 \cdot 9 \pm 6 \cdot 5(\mathrm{c}) \\
77 \cdot 4 \pm 2 \cdot 8(\mathrm{~d}) \\
100 \cdot 1 \pm 5 \cdot 1(\mathrm{c}, \mathrm{d})\end{array}$ & $\begin{array}{l}278 \pm 22 \\
316 \pm 31 \\
248 \pm 41 \\
(284 \pm 53)^{1} \\
286 \pm 34\end{array}$ & $\begin{array}{l}273 \pm 36(e) \\
348 \pm 55 \\
358 \pm 65 \\
(409 \pm 43)^{1}(e) \\
275 \pm 71\end{array}$ & $\begin{array}{l}24 \cdot 2 \pm 2 \cdot 2 \text { (f) } \\
27 \cdot 5 \pm 1 \cdot 3 \\
31 \cdot 5 \pm 5 \cdot 9 \\
(36 \cdot 1 \pm 4 \cdot 1)^{1}(f) \\
25 \cdot 4 \pm 5 \cdot 2\end{array}$ \\
\hline
\end{tabular}

Figures following \pm signs are standard errors of the means.

'Excluding one stomach of very small area (see text).

Statistical Analyses:

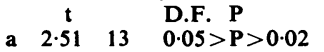

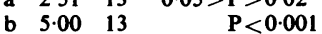

$\begin{array}{cclc} & \text { t } & \text { D.F. } & \text { P } \\ \text { c } & 3.77 & 13 & 0.01>\text { P }>0.001 \\ \text { d } & 3.92 & 10 & 0.01>\text { P }>0.001\end{array}$

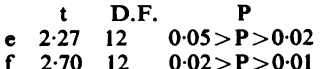

Other differences between means are not significant at the $5 \%$ level.

parietal cells per unit area was increased in five of the six stomachs, the mean difference being $33 \%$.

EXPERIMENT II (Table III) The results have been analysed in terms of three main ranges of total dosage, which we have called 'low', 'moderate', and 'high' (Table I). The differences between the subgroups are small and insignificant in comparison with those between these three main groups.

The total height of the mucosa varied very little in the control animals and its mean was similar to that of the control specimens in the first experiment. It showed a mean increase of $20 \%$ with the low dosage of cortisone (group II) and of $27 \%$ with the moderate dosage (group III). The high dosage (group IV) did not affect the mean height, although it produced a very large range of measurements.

An increase in the mean number of parietal cells underlying a unit area $(1,000 \mu \times 7 \mu)$ of the mucosal surface accompanied (or followed) the thickening of the mucosa (Fig. 1). The effect was insignificant with the low dosage (group II), but there was an increment of $50 \%$ with the moderate dosage (group III). The high dose again produced a large range of counts, but did not influence the mean (group IV). Of the seven counts one was above the control range, suggesting stimulation, and two were below the control range, indicating inhibition.

The area of the gastric mucosa varied greatly in all groups. The variation was not related to that of the height of the mucosa or of the numbers of parietal cells, and the mean area was not influenced significantly by cortisone. The mucosa of one dog in group III had an area far smaller than that of any other dog, although it was normal in other respects. (It measured $67 \mathrm{sq} . \mathrm{cm}$., the next smallest, one of the controls, being $165 \mathrm{sq} . \mathrm{cm}$.) If this dog is excluded from the analysis (as seems reasonable) the total number of parietal cells in the stomach (the product of the area $\times$ the number of cells per unit area) showed mean changes very similar to those of the number of cells underlying a unit area, the increment again being $50 \%$ with moderate doses of cortisone (group III). If the dog is included the increase in the mean is insignificant. Calculation of the number of parietal cells per kilogram of body weight makes little difference to the results.

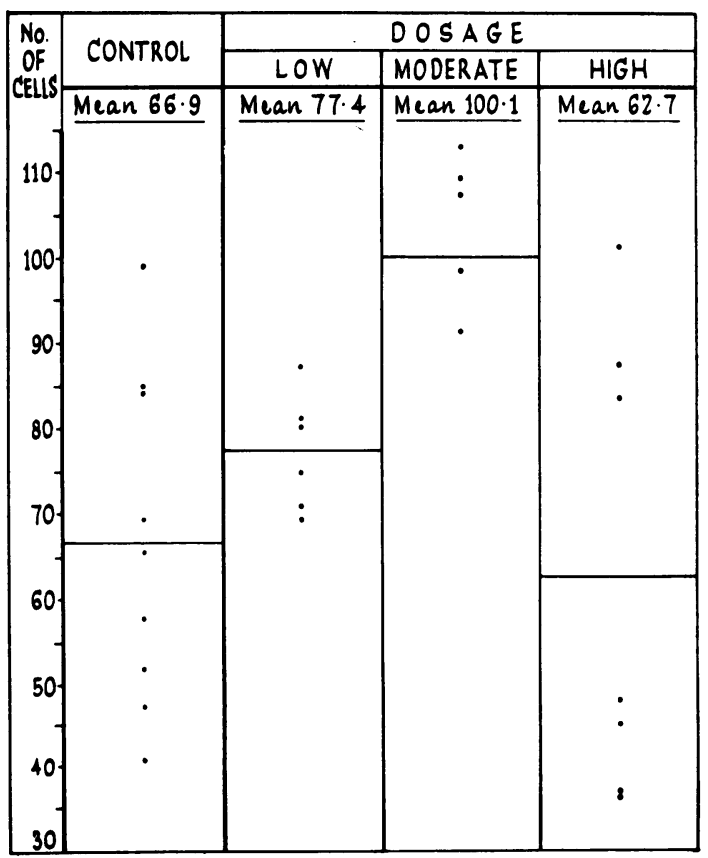

FIG. 1. The influence of cortisone on the number of parietal cells per 7,000 sq. $\mu$ of gastric mucosal surface. 


\section{DISCUSSION}

There can be little doubt that cortisone, within the range of dosage which we have called 'moderate', causes an increase of about $50 \%$ in the number of parietal cells in the stomach. The time of administration is, however, a critical factor. Thus a daily dose of 8.7 to $8.9 \mathrm{mg}$. per $\mathrm{kg}$. for two days had little, if any, effect while in three days it caused a definite increase; in seven days the effect was no longer apparent. It seems probable that the high total doses $(8.7 \mathrm{mg}$. or more per $\mathrm{kg}$. per day for seven to 10 days) caused an increase initially and then a reduction. All the animals in the high dose group (IV) had passed through a phase in which the total dosage had been 'moderate' and presumably they had had a uniform increase in their parietal cells at this time. By the end of the experiment some had very high cell counts and others had very low ones. The increases in the cell count and in the mucosal heights were rather smaller in the first experiment than in the second and showed considerable variation. The explanation may be that the sampling of the gastric mucosa was much less extensive.

It is likely that the increase in the parietal cell population represents a 'work hyperplasia', for similar increases have been observed in the guineapig (Cox and Barnes, 1945) and in the dog (Tongen, 1950) after prolonged stimulation with histamine. The significance of the increase in mucosal height is not clear. The increase in the number of parietal cells may be partly responsible for it, but detailed information about the other cellular elements and the interstitial tissues is not available.

The average number of parietal cells per unit area in the control dogs in this investigation was about one-third of the number found by Tongen (1950) and by Marks, Komarov, and Shay (1958) in dogs of similar weight, and the average total number of parietal cells in the stomach was about one fifth of the number found by the latter authors. ${ }^{1}$ The numbers of cells in our dogs were similar to those found in patients with gastric ulcer by Card and Marks (1960), while the numbers in the other

${ }^{1}$ To avoid confusion it should be pointed out that Marks et al. used 'billion' in the French or American sense of ' 10 "' and not in the British sense of ' $10^{12}$,' investigations were similar to those in patients with duodenal ulcer. There is no obvious reason for this difference. The cell counts in our two experiments were made independently (that in the first by R.M.H. and that in the second by N.C.R.W.R.) and the means of the two control groups agreed closely (64.4 and 66.9 respectively, Tables II and III). If there was a systematic error in our observations it is unlikely to have influenced the relative estimates, although it would have affected the absolute ones.

It is interesting to note that there is a general similarity between these effects of cortisone on the parietal cell population and those which we noted previously on the secretion of acid. This is seen in the level of dosage which causes stimulation, in the latent period of about three days before a definite effect is observed, and in the inhibitory action of large doses. Finally, the increase in parietal cell population is very similar to that of the maximal acid secretory response to histamine. It is reasonable, therefore, to assume a cause-and-effect relationship between them.

We wish to thank Professor J. H. Biggart for facilities in his department, Dr. J. B. Gibson for much helpful advice, Dr. J. T. Ward and Messrs. H. O. Nevin and E. H. Crozier for technical assistance, Mr. G. Smith for the figures, and Miss H. N. Pountain for secretarial help. We are grateful to Dr. E. W. Tapley and Roussel Laboratories Ltd. for supplies of cortisone.

\section{REFERENCES}

Abercrombie, M. (1946). Estimation of nuclear population from microtome sections. Anat. Rec., 94, 239-247.

Card, W. I., and Marks, I. N. (1960). The relationship between the acid output of the stomach following "maximal" histamine stimulation and the parietal cell mass. Clin. Sci., 19, 147-163.

Clarke, S. D., Neill, D. W., and Welbourn, R. B. (1960). The effects of corticotrophin and corticoids on secretion from denervated gastric pouches in dogs. Gut, 1, 36-43.

Cox, A. J. (1952). Stomach size and its relation to chronic peptic ulcer. A.M.A. Arch. Path., 54, 407-422.

- and Barnes, V. R. (1945). Experimental hyperplasia of the stomach mucosa. Proc. Soc. exp. Biol. (N.Y.), 60, 118-120.

Crean, G. P. (1960). The effects of A.C.T.H. and corticosteroids on gastric secretion in humans. Gut, 1, 82.

Marks, I. N., Komarov, S. A., and Shay, H. (1958) Acid secretory responses to histamine and the parietal cell mass in the dog. Amer. J. Physiol., 195, 528-534.

Tongen, L. A. (1950). The quantitative relationship between parietal cells and gastric acidity. Surgery, 28, 1009-1015. 